\title{
The Effect of Service Quality and Promotion on Purchase Intention Mediated by Trust (Case Study: PT China Taiping Insurance Indonesia)
}

\author{
Achmad Buchori and Yuli Harwani
}

\section{ABSTRACT}

\begin{abstract}
This study aims to analyze the effect of service quality and promotion on purchase intention mediated by trust. The object of this study is PT China Taiping Insurance Indonesia and the number of samples used in this study 170 respondents using the heir formula calculation method which was multiplied by 5 . The sampling method used purposive sampling method, the data collection method used the questionnaire method and data analysis used Partial Least. Square (PLS). The results show that service quality has a positive and significant effect on trust, promotion has a significant effect on trust, trust has a positive and significant effect on purchase intention, service quality has a positive and significant effect on purchase intention, promotion has a positive and significant effect on purchase. intention, service quality has a positive and significant effect on purchase intention through trust, and promotion has a positive and significant effect on purchase intention through trust.
\end{abstract}

Keyword: Service Quality, Promotion, Purchase Intention, Trust.

\author{
Submitted : February 23, 2021 \\ Published : March 16, 2021 \\ ISSN: $2507-1076$ \\ DOI: $10.24018 /$ ejbmr.2021.6.2.764 \\ Achmad Buchori* \\ Universitas Mercu Buana Jakarta, \\ Indonesia. \\ (e-mail: achmad.bucorey@gmail.com) \\ Yuli Harwani \\ Universitas Mercu Buana Jakarta, \\ Indonesia. \\ (e-mail: yuli_harwani@mercubuana.ac.id) \\ *Corresponding Author
}

\section{INTRODUCTION}

According to the Central Statistics Agency (BPS), data on foreign and domestic tourist visits each year are dominant. This is evidenced by the number of foreign tourist visits from 2015 to 2019 which has always increased. Then domestic tourist visits from 2015 to 2018 have always increased, even though in 2018 to 2019 there have been fluctuations.

By increasing the tourism sector in Indonesia, it certainly creates opportunities for companies engaged in general insurance. One of the general insurance companies in Indonesia is PT. China Taiping Insurance Indonesia, which was founded in 1996. One of the products developed along with the increasing tourism industry both at home and abroad is Travel Insurance or known as Travel Insurance.

\begin{tabular}{ccc}
\multicolumn{4}{c}{ TABLE I: TRAVEL INSURANCE DATA 2019 } \\
\hline Company & Premi & Klaim \\
\hline Allianz Utama Ind. & 642.985 & 345.084 \\
Cakrawala Proteksi & 395.309 & 66.640 \\
XL China Taiping Insurance Ind & 12.858 & 3.736 \\
\hline
\end{tabular}

PT China Taiping Insurance Indonesia is still lagging behind other competing companies. In addition, the authors also get data on the travel insurance premiums of PT China Taiping Insurance Indonesia via the website which shows that the premiums of travel insurance products via the website have decreased every year. This is inversely proportional to the data on the number of tourist visits which dominantly increases each year.

The decline in sales of travel insurance premiums via the website at PT China Taiping Insurance Indonesia shows that there is a decrease in buying interest or purchase intention. Interest in a product arises because of the basic trust in the product accompanied by the ability to buy the product. In addition, buying interest in a product can also occur with the influence of other people who are trusted by potential customers. Increased ability to buy leads to an increase in the likelihood of buying.

\section{LITERATURE REVIEW}

\section{A. Purchase Intention}

Purchase intention is a consumer's tendency to buy a brand or take action related to a purchase as measured by the consumer's likelihood of making a purchase. Purchase intention is defined as something that is obtained from the process of studying and thinking that forms perceptions [1].

Ferdinand explained that indicators of purchase intention can be explained as follows [2]:

1) Transactional interest can be interpreted as the tendency of consumers to always repurchase the products they have consumed.

2) Referential interest means the willingness of consumers to recommend products they have consumed to others.

3) Preferential interest related to consumer behavior to make a product the top choice.

4) Exploratory interest related to the desire of consumers to always seek information about the products they are interested in. 


\section{B. Trust}

Customer trust is a very powerful weapon in building relationships because of the high level of customer trust in a company, making the company strong in building relationships with its skateholder groups [3].

Through various experiences, consumers gain a lot of trust regarding the products, brands, and other objects around them. The key to understanding consumer attitudes is identifying and understanding the basis for this belief.

Zikmud explained the following trust indicators [4]:

1) Trust in the company. Consists of believing in the company and believing in the integrity of the company.

2) Believe in the service or product. Consists of believing in the performance of the product or service and believing in the features of the product or service.

3) Trust in the brand. Consists of believing in brand reliability.

\section{Service Quality}

Hardiansyah defines service quality as an assessment of service quality as a global consideration or attitude related to the superiority of a service [5]. Zeithamal and Bitner argue that service quality or service is the delivery of good or very good service, when compared to customer expectations.

In measuring service quality, Tjiptono compiles several indicators as follows [6]:

1) Reliability. Has indicators of accuracy of information, reliability of officers in smoothing service procedures, and facilitates technical services.

2) Guarantee. Has indicators of the responsibility given by the company to consumers, the administrative skills of service officers, and the technical capabilities of service officers.

3) Empathy. It has indicators of a 24-hour contact center service, staff concern, and friendliness of service personnel.

\section{Promotion}

Promotion is an activity to communicate with customers so that customers are expected to be able to receive the message conveyed by the seller and the seller is able to achieve the objectives of the sales program to attract customers to buy the product being promoted [7]. Tjiptono compiled several indicators, namely [8]:

1) Advertising. The form of non-personal presentations and promotions that require costs for ideas, goods or services by a clear sponsor.

2) Events and Experiences. Company sponsored activities and programs designed to create special or everyday branding.

3) Public relations and publicity. Build good relations with various public companies in a number of ways,

4) Personal Selling. Personal presentation by a company's sales rep with the aim of generating sales transactions and building customer relationships.

\section{Methodology ReSEARCH}

Based on existing theories and dimensions, the researcher makes a research framework.

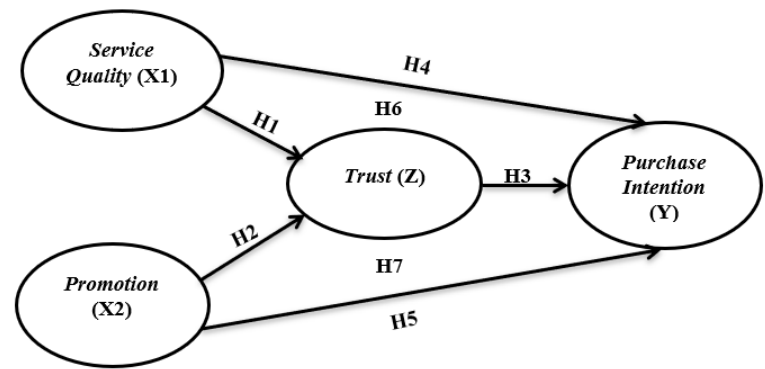

Fig. 1. Framework.

The population analyzed was the consumers of PT China Taiping Insurance Indonesia with a total sample of 200 respondents using the Hair et al. Technique. Data were analyzed using IBM SPSS Statistic 23 for descriptive analysis and Partial Least Square (PLS) for hypothesis testing.

\section{RESULT}

\section{A. Descriptive Respondent Answer}

Descriptive statistics are used to interpret the number of respondents' answers and see the mean of the indicators for each variable used in the model. From the statistics obtained in this study, it can be explained that the 34 instrument items were submitted to 170 respondents.

Based on the results of processing, the indicator of the service quality variable with the highest mean value among other indicators is the SQ9 indicator with the questionnaire "Very friendly service staff" with a mean value of 4.141. Meanwhile, the indicator with the lowest mean value on the service quality variable is the SQ1 indicator with the questionnaire "Information provided by officers is very accurate" with a mean value of 3.447.

The indicator of the promotion variable with the highest mean value among other indicators is the indicator P12 with a questionnaire question "The explanation of the product delivered is very clear and easy to understand" the mean value is 4.065. Meanwhile, the indicator with the lowest mean value on the promotion variable is the indicator P11 with the questionnaire question "Service officers give free time to provide information in maintaining relationships" mean value 3.529 .

The indicator of the trust variable with the highest mean value among other indicators is the T4 indicator with the questionnaire question "I believe in the usefulness of the product" mean value of 4.106. Meanwhile, the indicator with the lowest mean value on the trust variable is the T3 indicator with the question "I believe in product performance" with a mean value of 3.765 .

The indicator of the purchase intention variable with the highest mean value among other indicators is the PI6 indicator with the questionnaire question "I like the product offered" with a mean value of 3.959. Meanwhile, the indicator with the lowest mean value on the purchase intention variable is the PI1 indicator with the questionnaire "I tend to buy products from PT China Taiping Insurance Indonesia" with a mean value of 3.529 .

\section{B. Hypothesis Result Testing}

The results of hypothesis testing can be indicated by the $T$ Statistic value where the recommended value must be above 1.96 . 


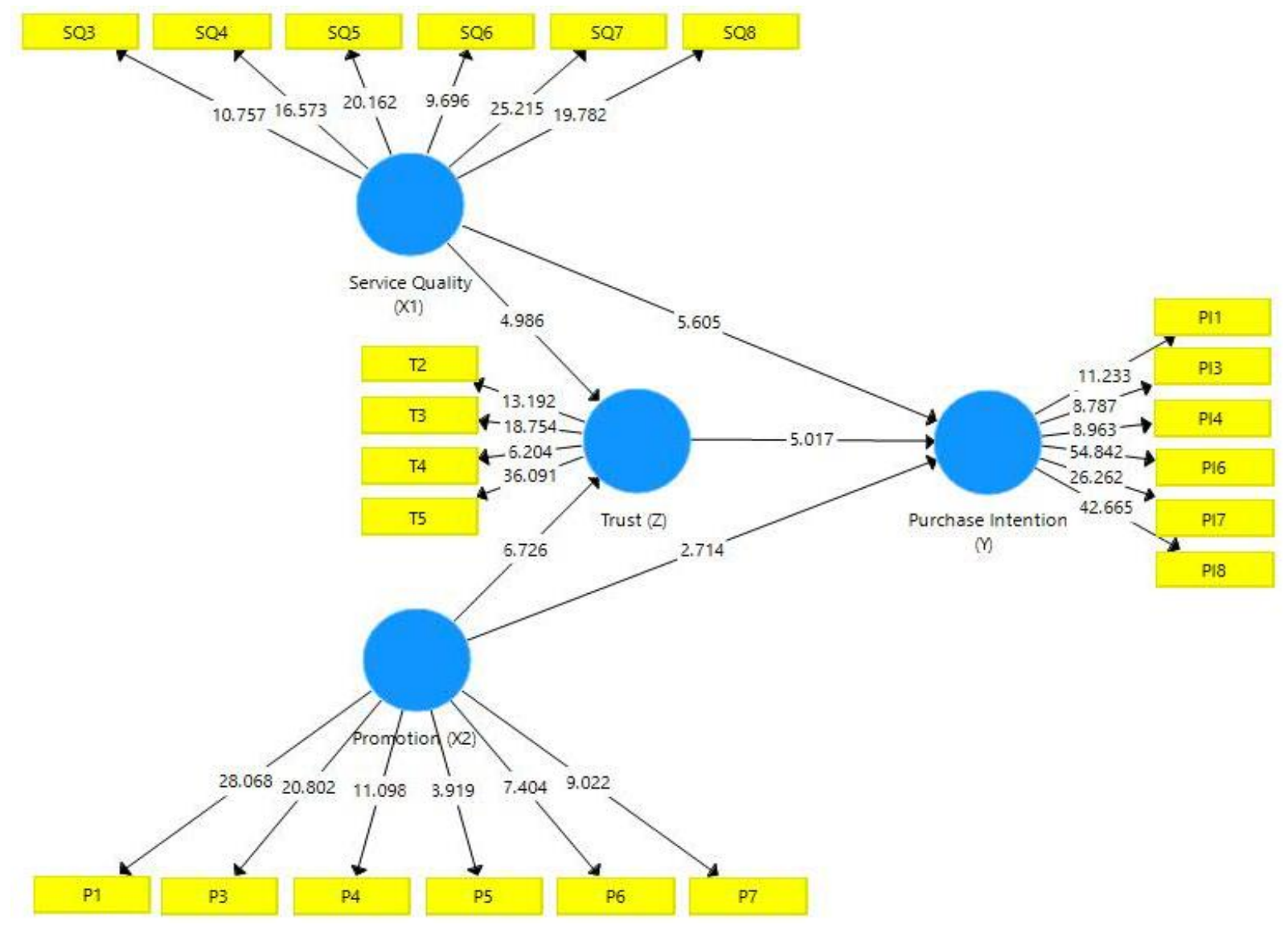

Fig. 2. Bootstrapping Results.

1) Based on the results of hypothesis testing in this study, it shows that service quality has a positive and significant effect on trust. This is evidenced by the $\mathrm{T}$ statistic is greater than the $\mathrm{T}$ table $(5.986>1.96)$ or a $\mathrm{P}$ value of $0.000<0.05$, and with the original sample of 0.347 which shows a positive direction of the relationship.

2) Based on the results of hypothesis testing in this study, it shows that there is a positive and significant influence between promotion on trust. This result is because the $\mathrm{T}$ statistic is greater than the T table $(6.726>1.96)$ or the $\mathrm{P}$ value is $0.000<0.05$, and the original sample value is 0.461 which shows a positive direction of the relationship.

3) Based on the results of hypothesis testing in this study, it shows that trust has a positive and significant effect on purchase intention. This result is because the $\mathrm{T}$ statistic is greater than the $\mathrm{T}$ table $(5.017>1.96)$ or the $\mathrm{P}$ value is $0.000<0.05$, and the original sample value is 0.370 which indicates a positive direction of the relationship.

4) Based on the results of hypothesis testing in this study, it shows that service quality has a positive and significant effect on purchase intention. This result is because the $\mathrm{T}$ statistic is greater than the $\mathrm{T}$ table $(5.605>1.96)$ or the $\mathrm{P}$ value is $0.000<0.05$, and the original sample value is 0.352 which indicates a positive direction of the relationship.

5) Based on the results of hypothesis testing in this study, it shows that promotion has a positive and significant effect on purchase intention. This result is because the T statistic is greater than the $\mathrm{T}$ table $(2.714>1.96)$ or the $\mathrm{P}$ value is $0.007<0.05$, and the original sample value is 0.191 which indicates a positive direction of the relationship.

6) Based on the results of hypothesis testing in this study, it shows that service quality has a positive and significant effect on purchase intention through trust. This result is because the $\mathrm{T}$ statistic is greater than the $\mathrm{T}$ table (3.534 > 1.96 ) or the $\mathrm{P}$ value is $0.000<0.05$, and the original sample value is 0.129 which indicates a positive direction of the relationship.

7) Based on the results of hypothesis testing in this study, it shows that promotion has a positive and significant effect on purchase intention through trust. This result is because the $\mathrm{T}$ statistic is greater than the $\mathrm{T}$ table $(4.087>1.96)$ or the $\mathrm{P}$ value is $0.000<0.05$, and the original sample value is 0.171 which shows a positive relationship.

\section{DISCUSSION}

\section{A. Effect of Service Quality on Trust}

The results of this study can be interpreted if the quality of services provided can be improved, it will give consumers confidence in PT China Taiping Insurance Indonesia. PT China Taiping Insurance Indonesia service officers can provide friendly service to consumers, pay attention to consumers, and can establish smooth communication with consumers, so that for consumers service quality is the dominant factor in determining consumer interest in using products from PT China Taiping Insurance Indonesia. The results of this study are supported by research conducted by Alhartey which states that service quality has a significant effect on trust [9]. Furthermore, the same result is stated by the research conducted by Misbach that there is a positive and significant influence between service quality on trust [10]. 


\section{B. Effect of Promotion on Trust}

The results of hypothesis testing in this study can be interpreted if promotional activities are often held or increased, it will affect consumer confidence in the company. The rise of travel insurance companies in Indonesia has made PT China Taiping Insurance Indonesia have to be able to attract consumers with attractive promotional activities starting from using advertisements on YouTube, using the role of influencers as brand ambassadors, or making advertisements on television. The results of this study are supported by research conducted by Wijayanto which states that promotion has a positive and significant effect on trust [11]. Furthermore, the same result is stated by Suhartini et al, that there is a significant influence between promotion on trust.

\section{The Effect of Trust on Purchase Intention}

The results of hypothesis testing in this study can be interpreted that by increasing public trust, it can increase public interest in buying or using the products offered by PT China Taiping Insurance Indonesia. The results of this study are supported by research conducted by Bakhtiar and Sunarka which states that there is a positive and significant influence between trust on purchase intention. Furthermore, research conducted by Ponte et al also stated the same results, that trust has a significant effect on purchase intention.

\section{Effect of Service Quality on Purchase Intention}

The results of hypothesis testing in this study can be interpreted if the quality of service continues to be improved, it will affect people's buying interest. The results of this study are supported by research conducted by Handoko which states that service quality has a positive and significant effect on purchase intention [12]. And research conducted by Hermanto also states that there is a significant relationship between service quality and purchase intention [13].

\section{E. Effect of Promotion on Purchase Intention}

The results of hypothesis testing in this study can be interpreted if promotional activities continue to be held and increased, the public's buying interest will also increase. The results of this study are supported by research conducted by Hulu et al which states that promotion has a positive and significant effect on purchase intention [14]. And the results of research conducted by Monica also state the same thing that there is a positive and significant influence between promotion on purchase intention [15].

\section{F. The role of Trust mediates Service Quality on Purchase Intention}

The results of hypothesis testing in this study can be interpreted that by improving the quality of company services it will increase the company's credibility so that it can foster a sense of trust in potential customers and can increase purchase interest. The results in this study are supported by research conducted by Komaling and Suryani which states that trust is positive and significant in mediating service quality on purchase intention. And research conducted by Yuliani states that service quality has a positive and significant effect on trust and purchase intention.

\section{G. The role of Trust mediates Service Quality on Purchase Intention}

The results of hypothesis testing in this study can be interpreted by increasing promotional activities, it will make the company's capabilities increase in the minds of potential consumers so that it can foster consumer confidence and can increase purchase interest. The results in this study are supported by research conducted by Suhartini et al which states that trust is positive and significant in mediating promotion on purchase intention. And research conducted by Nur et al. Stated that promotion has a positive and significant effect on trust and purchase intention.

\section{CONCLUSION}

The results show that trust can mediate the effect of service quality and promotion on purchase intention. Suggestions for PT China Taiping Insurance Indonesia so that service officers are clearer and more detailed in providing information about services, product explanations, and promotional activities that are being held by the company. In addition, it is recommended that further researchers develop and use other variables such as brand image, word of mouth, price, product quality and others. In addition, for researchers who will conduct research in the same field and use this thesis as a reference, it is necessary to re-examine it because it does not rule out that there are unsuitable statements [16].

\section{REFERENCES}

[1] Bakhtiar, M. R., \& Sunarka, P. S. (2019). Keamanan, Kepercayaan, Harga, Kualitas Pelayanan Sebagai Pemicu Minat Beli. Jurnal Ilmu Manajemen Dan Akuntansi Terapan, 10(2), 133-148.

[2] Ferdinand, A. (2013). Metode Penelitian Manajemen. Badan Penerbit Universitas Diponegoro.

[3] Jasfar, F. (2012). Kunci Keberhasilan Bisnis Jasa. Salemba Empat.

[4] Zikmud, W. (2010). Business Research Methods (eight edition). Chengage Learning.

[5] Hardiansyah. (2011). Kualitas Pelayanan Publik: Konsep, Dimensi, Indikator dan Implementasinya. Gava Media.

[6] Tjiptono, F. (2016). Service Quality and Satisfaction. Andi.

[7] Kotler, P., \& Armstrong, G. (2014). Principle of Marketing (15th ed.). Pearson Pretice Hall.

[8] Tjiptono, F. (2015). Strategi Pemasaran (4th ed.). Andi Offset.

[9] Alhartey, D. B. K. (2019). Impact of service quality on customer trust, purchase intention and store loyalty, with mediating role of customer satisfaction and purchase intention. British Journal of Marketing Studies (BJMS), 7(2), 40-61. https://doi.org/10.3141/2230-10.

[10] Misbach, I. (2017). Pengaruh Islamic Bank Service Quality Terhadap Kepuasan dan Kepercayaan Nasabah Bank Umum Syariah. Jurnal Telaah Ekonomi Dan Bisnis, 1(1).

[11] Wijayanto, T., Rahadhini, M. D., \& Sumaryanto. (2018). Analisis Pengaruh Promosi terhadap Loyalitas Konsumen dengan Kepercayaan sebagai Variabel Mediasi. Jurnal Ekonomi Dan Kewirausahaan, 18(3), $370-378$.

[12] Handoko, K. F. (2017). Pengaruh Desain Visual Kemasan, Kualitas Informasi, Serundeng Mr. Gora Secara Online. PERFORMA: Jurnal Manajemen Dan Start-Up Bisnis, 2(5), 611-619.

[13] Hermanto, A. H. (2020). Pengaruh Harga Dan Kualitas Pelayanan Terhadap Minat Beli. Jurnal EKOBISTEK, 9(1), 93-99.

[14] Hulu, P., Ruswanti, E., \& Hapsari, N. P. (2018). Influence of Product Quality, Promotion, Brand Image, Consumer Trust towards Purchase Intention (Study Case on Pocari Sweat Isotonic Drink). IOSR Journal of Business and Management, 20(8), 55-61.

[15] Monica, E. (2018). Pengaruh Harga, Lokasi, Kualitas Bangunan dan Promosi Terhadap Minat Beli. International Journal of Science and Business, 2(3), 141-149.

Nur, A. M., Ghalib, S., \& Utomo Setio. (2020). Pengaruh Promosi Dan Harga Terhadap Minat Beli Yang Dimediasi Oleh Kepercayaan Pada Pelanggan Indihome Di Kota Palangka Raya” Studi. 9(1). 